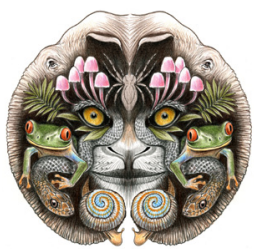

ISSN

Online 0974-7907

Print 0974-7893
The family Clethraceae is composed of two genera, Purdiaea with four species in Neotropics (Anderberg \& Zhang 2002) and Clethra L. with ca. 68 species (Willis, Dict. Fl. PI \& Ferns 261.

OPEN ACCESS 1973, revised by Airy-Shaw 1973; Wu et al. 2005) and distributed in continents Asia, America and Madeira, the archipelago. In Asia, concentration is in China with ca. 15 species ( $\mathrm{Hu}$ 1960). A few species are found in Malaysia (van Steenis 1958; Backer \& van den Brink 1965).

Species decription: Clethra delavayi Franchert (earlier treated as Clethra monostachya Rehder \& Wilson) is a shrub of 2-4 $\mathrm{m}$ in height with long terminal solitary racemes; distinguished by its elliptic leaves attenuate at ends, smaller flowers, papillose petals, pubescent filaments and styles. Sepals persistent, broadly ovate, papillose outside, and caducous. Stamens 10 in two whorls of 5; filaments shorter than petals, anthers dorsifixed, 2-lobed, v-shaped. Ovary superior; style short at anthesis; stigmas 3 (Rehder \& Wilson 1913; Hu 1960) (Images 1a,b).

In India, Clethra delavayi Franchert was first reported from Eaglenest Sanctuary, Kameng District, Arunachal Pradesh by Bennet \& Naithani in 1978. They identified the species as C. monostachya Rehder \& Wilson, a chinese species which is distributed in the mountains of Yunnan-Szechuan-Sikang borders of China, occurring on the margins of woods and thickets at altitudes of

\section{NEW DISTRIBUTION RECORDS ON THE OCCURRENCE OF THE DELAVAY SUMMERSWEET Clethra delavayı Franchert (Clethraceae), a Chinese species in Arunachal Pradesh, INDIA}

\section{Jis Sebastian ${ }^{1}$ \& H.B. Naithani ${ }^{2}$}

${ }^{1} \mathrm{PG}$ and Research Centre in Botany, S.H. College, Cochin, Kerala 682013, India

${ }^{2}$ Forest Research Institute, Dehradun, Uttarakhand 248001, India ${ }^{1}$ alkaeliza@gmail.com (corresponding author), ${ }^{2}$ naithanihb@icfre.org

1700-2800 m. The specific habitats were reported earlier, i.e., mixed or coniferous forest margins, open thickets, slopes to alpine regions of Chongqing, Fujian, Guangdong, Guangxi, Guizhou, Hubei, Hunan, Jiangxi, Sichuan, southeastern Xizang, Yunnan and Zhejiang, Bhutan, northeastern India, northern Myanmar and Vietnam (Shu 2005). The eastern Szechuan and western Yunnan are the western and northern limits of the range of the genus in China (Bennet $\&$ Naithani 1978). Interestingly, this was the first and the only report on the presence and distribution of the species in India.

After 34 years, the authors came across the blooming of $C$. delavayi from two new localities in Arunachal Pradesh apart from Eaglenest, the earlier known distribution. The survey was carried out from March to August in Arunachal Pradesh, the eastern most
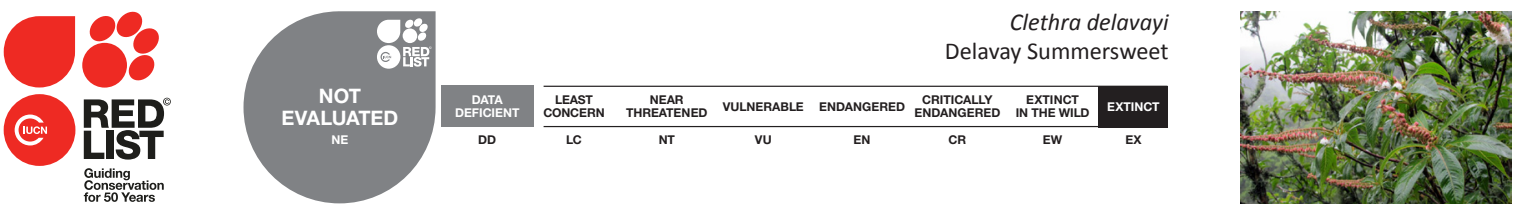

DOI: http://dx.doi.org/10.11609/JoTT.o3677.6376-8

Editor: K.S. Negi, National Bureau of Plant Genetic Resources, Uttarakhand, India

Date of publication: 26 September 2014 (online \& print)

Manuscript details: Ms \# 03677 | Received 24 June 2013 | Final received 28 August 2014 | Finally accepted 30 August 2014

Citation: Sebastian, J. \& H.B. Naithani (2014). New distribution records on the occurrence of the Delavay Summersweet Clethra delavayi Franchert (Clethraceae), a Chinese species in Arunachal Pradesh, India. Journal of Threatened Taxa 6(10): 6376-6378; http://dx.doi.org/10.11609/JoTT.03677.6376-8

Copyright: (C Sebastian \& Naithani 2014. Creative Commons Attribution 4.0 International License. JoTT allows unrestricted use of this article in any medium, reproduction and distribution by providing adequate credit to the authors and the source of publication.

Funding: Indian Council of Forestry Research and Education, Dehradun.

Competing Interest: The authors declare no competing interests.

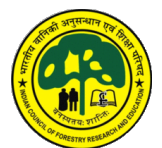

Acknowledgements: The work was carried out from Rain Forest Research Institute, Assam under the guidance of Indian Council of Forestry Research and Education, Dehradun. 


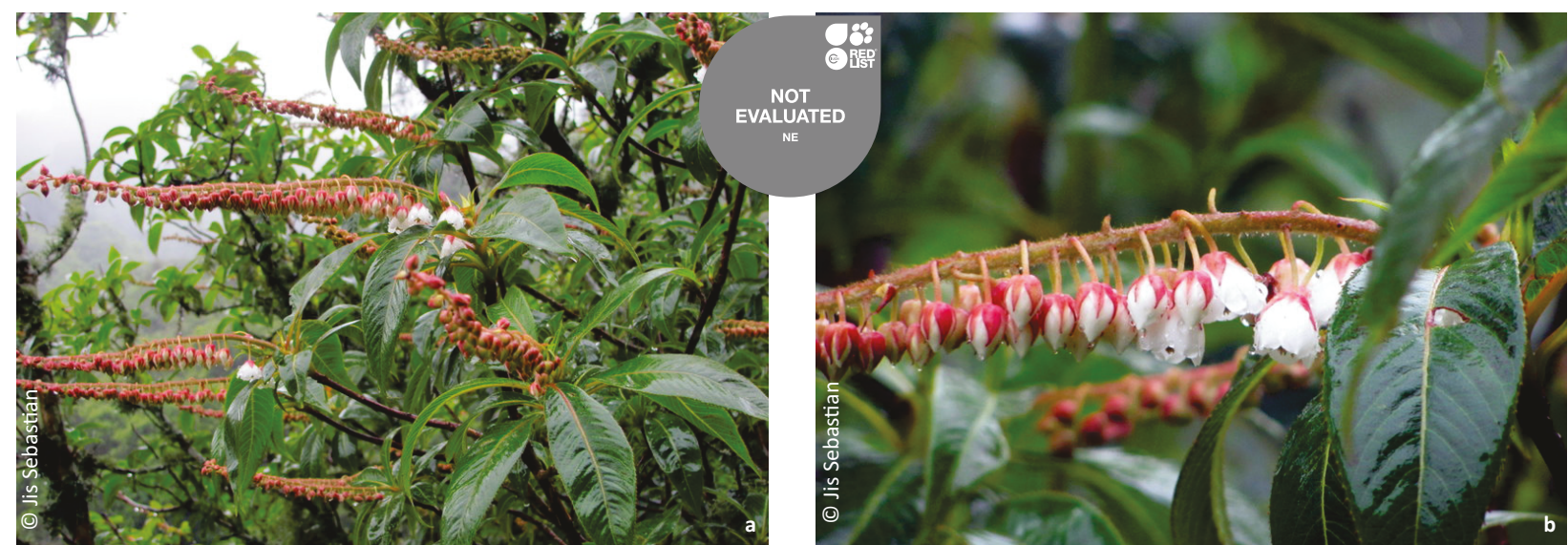

Image 1. Clethra delavayi Franchert at Eaglenest Wildlife Sanctuary, Arunachal Pradesh a - Habit; b - Inflorescence (July 2012)

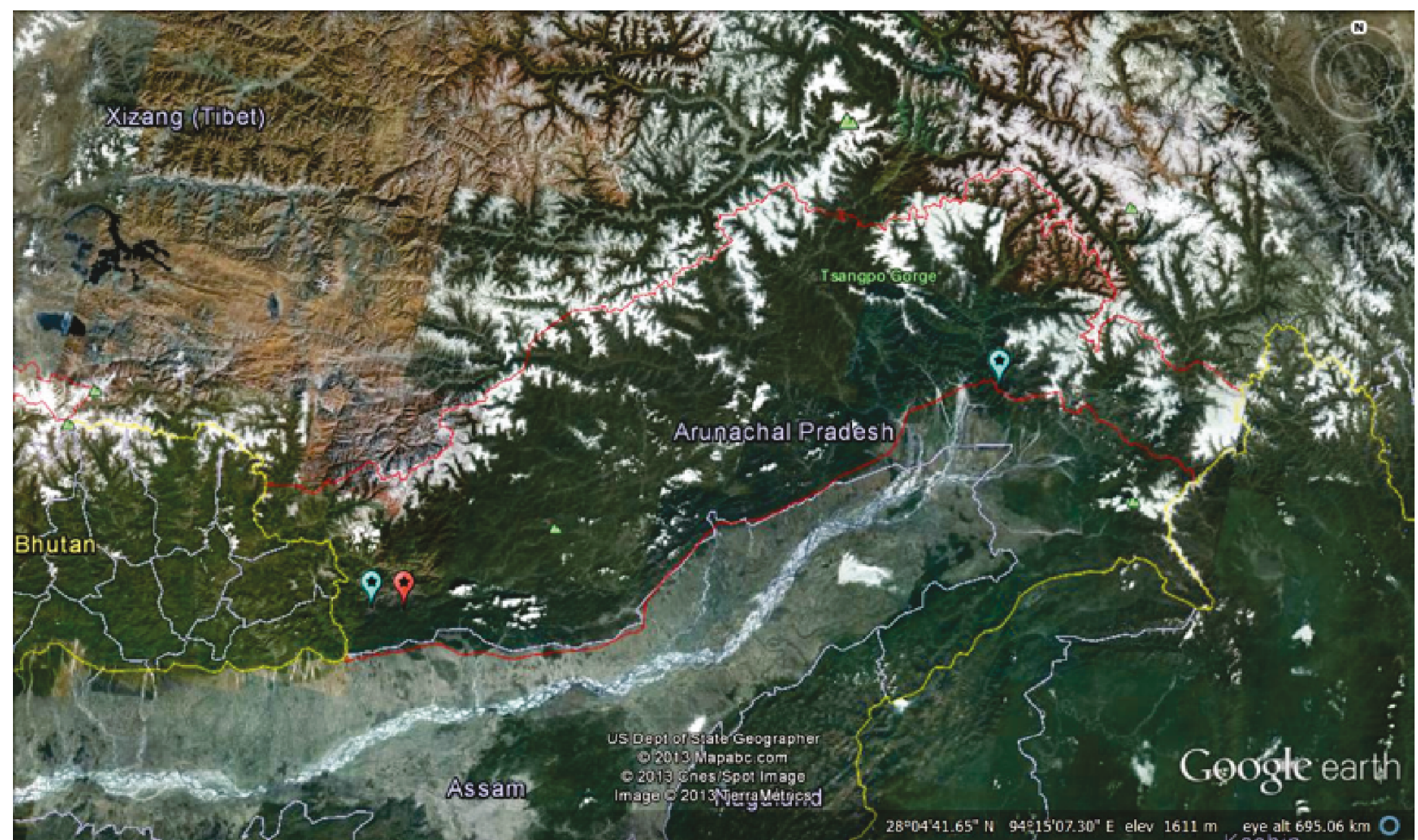

Image.2. The distribution (blue markings indicate new records) of Clethra delavayi in Arunachal Pradesh

Table 1. Passport information of Clethra delavayi in two districts of Arunachal Pradesh

\begin{tabular}{|l|l|l|l|l|}
\hline Distribution & GPS location & Altitude & Flowering period/ season & Forest type \\
\hline $\begin{array}{l}\text { Eaglenest Wildlife Sanctuary, } \\
\text { West Kameng }\end{array}$ & $\begin{array}{l}27^{\circ} 07^{\prime} 54.6^{\prime \prime} \mathrm{N} \& \\
92^{\circ} 27^{\prime} 01.6^{\prime \prime} \mathrm{E}\end{array}$ & $2714 \mathrm{~m}$ & July (wet season) & $\begin{array}{l}\text { Eastern Himalayan moist temperate (broadleaved) } \\
\text { forest }\end{array}$ \\
\hline Shergaon Road, West Kameng & $\begin{array}{l}27^{\circ} 07^{\prime} 50.1^{\prime \prime} \mathrm{N} \& \\
92^{\circ} 15^{\prime} 38.8^{\prime \prime} \mathrm{E}\end{array}$ & $1988 \mathrm{~m}$ & July (wet season) & $\begin{array}{l}\text { Eastern Himalayan moist temperate (broadleaved) } \\
\text { forest }\end{array}$ \\
\hline Mayudia Pass, Dibang Valley & $\begin{array}{l}28^{\circ} 14^{\prime} 45.1^{\prime \prime} \mathrm{N} \& \\
95^{\circ} 54^{\prime} 46.8^{\prime \prime} \mathrm{E}\end{array}$ & $2546 \mathrm{~m}$ & August (wet season) & $\begin{array}{l}\text { Eastern Himalayan moist temperate (broadleaved) } \\
\text { forest }\end{array}$ \\
\hline
\end{tabular}


state of India. Nested quadrats were used to quantify the vegetation diversity. Besides Eaglenest Wildlife Sanctuary, Shergaon in West Kameng District and Mayudia pass in Dibang Valley District were recorded with the species presence (Image 2). The eastern Himalayan moist temperate broadleaved forest (1800$2800 \mathrm{~m}$ ) is the belt where the species occurrence is associated with in the region (Table 1). Morphologically the population varies in all three locations, i.e., leaf shape, serration and floral characteristics. There are seemingly no other threats to the population at present but distinctive patchiness.

Detailed surveys to understand the distribution of the species in Arunachal Himalaya is emphasized.

\section{References}

Airy-Shaw, H.K. (1973). J.C. Willis's A Dictionary of the Flowering Plants and Ferns ( $8^{\text {th }}$ Edition). Cambridge University Press, $1245 \mathrm{pp}$. Anderberg, A. A. \& Z. Zhang (2002). Phylogenetic relationships of Cyrillaceae and Clethraceae (Ericales) with special emphasis on the genus Purdiaea. Organisms, Diversity \& Evolution 2: 127-137.

Backer, C.A. \& R.C.B. van den Brink (1965). Flora of Java. The Rijkshebarium, Leyden (Publications), II: 641pp.

Bennet, S.S.R. \& H.B. Naithani (1978). Clethraceae Klotzsch - new to Indian flora. Indian Journal of Forestry 1(3): 189-190.

Hu, S.Y. (1960). Clethra delaveyi. Journal of Arnold Arboretum 41: 182 Rehder \& E.H. Wilson (1913). Clethra monostachya.Sargent, PI. Wils. 1: 501.

van Steenis, C.G.G.J. (Ed.) (1958). Flora Malesiana. P.Noordhoff Ltd. (publication), 595pp.

Shu, Y.N.Q.Y. (2005). Clethra delaveyi 14: 240 In: Zhengyi, W., P.H.Raven \& H. Deyuan (eds.). Flora of China. Science Press and Missouri Botanical Garden. Internet http:// www.efloras.org (accessed 01 June 2013). 